\title{
Headache precipitated by Valsalva maneuvers in patients with congenital Chiari I malformation
}

\author{
Hugo André de Lima Martins', Valdenilson Ribeiro Ribas², \\ Murilo Duarte Costa Lima³, Daniella Araújo de Oliveira4, \\ Marcelo Tavares Viana ${ }^{5}$, Ketlin Helenise dos Santos Ribas ${ }^{6}$, \\ Marcelo Moraes Valença ${ }^{7}$
}

\begin{abstract}
The objective of this study was to characterize the headache precipitated by Valsalva maneuvers associated with Chiari type I malformation (CM-1). Nineteen patients were evaluated, with ages ranging from 30 to 75 years. Ten of them presented headache. Pain was more prevalent in the occipital $(80 \%)$ and frontal region (60\%). The headaches were of significantly shorter duration in the women compared with the men. The frequency of headache crises was relatively high. All patients with Valsalva-related headache suffered from at least one episode per month. The most prevalent precipitating factors were coughing, which is well described in the literature, and sexual activity, which only now is recognized as an event associated with $\mathrm{CM}-1$.
\end{abstract}

Key words: headache, Chiari type 1.

Cefaléia precipitada por manobras de Valsalva em pacientes com malformação congênita de Chiari tipo I

\section{RESUMO}

Neste estudo, objetivou-se caracterizar a cefaléia desencadeada por manobra de Valsalva, em portadores de malformação de Chiari tipo 1 (MC-1). Foram avaliados 19 pacientes com idades variando entre 30 e 75 anos. Dentre estes, 10 apresentaram cefaléia. A região mais acometida foi a occipital (80\%) e frontal (60\%). A cefaléia foi de duração bem menor nas mulheres em relação aos homens. A freqüência da cefaléia foi relativamente alta, com todos os pacientes apresentando pelo menos um episódio por mês. Os principais fatores desencadeantes foram a tosse, que já é bem descrita pela literatura, e a atividade sexual, que apenas recentemente foi associada a MC-1.

Palavras-chave: cefaléia, Chiari tipo 1.

In a pioneering study conducted at the Federal University of Pernambuco in the late 1960s, Barros et al. reported that headache was present in $53 \%$ of 66 patients with basilar impression and Chiari malformation (CM-1). The authors also noticed at that time that $28 \%$ of the pa- tients complained of pain in the nape of the neck, which was triggered by coughing, sneezing, effort and even laughing ${ }^{1,2}$. CM1 is a developmental anomaly at the base of the brain that was first identified in 1891 by the pathologist Hans Chiari ${ }^{1-6}$. It is a complex group of disorders charac-
Correspondence Hugo André de Lima Martins Av. Armindo Moura 581 Quadra D - Bloco 2 / Apto. 201 51130-180 Recife PE - Brasil E-mail: hugomt2001@yahoo.com.br

Received 1 June 2009

Receveid in final form 10 September 2009 Accepted 15 September 2009
'Master in Neurology, Post Graduation in Neuropsychiatry and Behavior Science, Universidade Federal de Pernambuco (UFPE),Recife PE, Brazil; ' 2 Doctor in Neuroscience, Post Graduation in Neuropsychiatry and Behavior Science, UFPE; ${ }^{3}$ Doctor in Medicine, Post Graduation in Neuropsychiatry and Behavior Science, UFPE; ${ }^{4}$ Doctor in Neuroscience, Post Graduation in Neuropsychiatry and Behavior Science, UFPE; ${ }^{5}$ Doctor in Experimental Bases of the Nutrition, Post Graduation in Neuropsychiatry and Behavior Science, UFPE; ${ }^{6}$ Student of college in Physiotherapy, Keizo Asami Immunopathology Laboratory, UFPE; ${ }^{7}$ Post-Doctor in Neurosurgery, National Institutes of Health (Visiting Fellow, 1983-1987; 1990), USA; University of London (Neurosurgery, 1995), Post graduation in Neuropsychiatry and Behavior Science, UFPE. 
terized by herniation of the cerebellum through the foramen magnum into the spinal canal. The herniated tissue blocks the bidirectional flow of cerebrospinal fluid through the foramen magnum separating the intracranial compartment from the intradural spinal compartment. It is generally regarded as a congenital malformation, although acquired cases have been recognized ${ }^{7,8}$. Nowadays, CM-1 is diagnosed by magnetic resonance, which accurately shows cerebellar tonsil hernia, as well as syringomyelia and bone abnormalities (basilar impression and platybasia) occurring at the craniocervical junction. Many patients with CM-1 may have no symptoms. When symptoms are present, they typically do not appear until adolescence or early adulthood, but are rarely present in young children ${ }^{7,9}$. In addition to headache, patients with Chiari I malformation frequently complain of dizziness, disequilibrium, visual disturbances, tinnitus, difficulty in swallowing, palpitations, sleep apnea, muscle weakness, impaired motor skills, chronic fatigue and painful tingling of the hands and feet ${ }^{2}$. Because of the complex symptomatology, this heterogeneous clinical entity is frequently misdiagnosed.

Headache is a frequent complaint among patients with $\mathrm{CM}-1$, and is reported as present in $40-70 \%$ of patients ${ }^{8,10,11}$. A number of different types of headache have been associated with CM-1, including the following: headache of short duration associated with coughing and Valsalva maneuver, CSF hypotension headache, headache of long duration with cervicogenic features and a type classified as continuous headache. No headache type is specifically linked to CM-1, although headache associated with coughing is frequently encountered in patients with $\mathrm{CM}-1^{12-14}$.

The objective of the present study was to evaluate the presence of short-lived headaches triggered by activities that might increase intra-abdominal pressure (Valsalva maneuver) in patients with CM-1.

\section{METHOD}

This study consisted of a series of 19 patients (10 men) with CM-1, with ages ranging from 30 to 75 years. The patients were evaluated at the Federal University of Pernambuco Hospital between January 2005 and December 2005. All the patients were studied by means of MRI. The diagnosis of CM-1 was made when: either [A] at least one of the cerebellar tonsils was positioned $5 \mathrm{~mm}$ or more below the foramen magnum or $[\mathrm{B}]$ when both cerebellar tonsils were located 3-5 mm below the foramen magnum.

The headache characteristics were assessed at the initial visit through a thorough work-up, including a general and neurological physical examination. The diagnosis of the headache type was based on the revised classification criteria of the International Headache Society (ICHD-II). The data are shown as mean \pm SD. Since the variables did not present normal distribution, we used the nonparametric Mann-Whitney test. All patients gave their written consent to participation in the study, which was approved by the Ethics Committee of the Federal University of Pernambuco.

\section{RESULTS}

The Table shows the demographic and Valsalva-related headache characteristics observed in the ten patients studied. Nine out of the 19 patients (52.6\%) with CM1 mentioned the presence of headaches triggered by Valsalva maneuvers. The following headache types were identified: associated with coughing (6/10), associated with sexual activity (6/10), associated with effort (5/10), associated with sneezing $(1 / 10)$ and associated with laughter

Table. Characteristics of study participants.

\begin{tabular}{ccccccccc}
\hline $\begin{array}{c}\text { Number of } \\
\text { patients }\end{array}$ & Gender & $\begin{array}{c}\text { Age } \\
\text { (years) }\end{array}$ & $\begin{array}{c}\text { Duration } \\
\text { of pain } \\
\text { (min) }\end{array}$ & $\begin{array}{c}\text { Nature } \\
\text { of pain }\end{array}$ & $\begin{array}{c}\text { Age at } \\
\text { pain onset } \\
\text { (years) }\end{array}$ & $\begin{array}{c}\text { Frequency } \\
\text { per month }\end{array}$ & Topography & Trigger factors \\
\hline 1 & M & 43 & 15 & Pulsatile & 25 & 2 & Frontal & Coughing, physical effort, sex \\
1 & M & 43 & 15 & Pulsatile & 25 & 2 & Frontal & Coughing, physical effort, sex \\
1 & M & 43 & 15 & Pulsatile & 25 & 2 & Frontal & Coughing, physical effort, sex \\
1 & M & 43 & 15 & Pulsatile & 25 & 2 & Frontal & Coughing, physical effort, sex \\
1 & M & 43 & 15 & Pulsatile & 25 & 2 & Frontal & Coughing, physical effort, sex \\
1 & M & 43 & 15 & Pulsatile & 25 & 2 & Frontal & Coughing, physical effort, sex \\
1 & M & 43 & 15 & Pulsatile & 25 & 2 & Frontal & Coughing, physical effort, sex \\
1 & M & 43 & 15 & Pulsatile & 25 & 2 & Frontal & Coughing, physical effort, sex \\
1 & M & 43 & 15 & Pulsatile & 25 & 2 & Frontal & Coughing, physical effort, sex \\
1 & M & 43 & 15 & Pulsatile & 25 & 2 & Frontal & Coughing, physical effort, sex \\
1 & M & 43 & 15 & Pulsatile & 25 & 2 & Frontal & Coughing, physical effort, sex \\
\hline
\end{tabular}




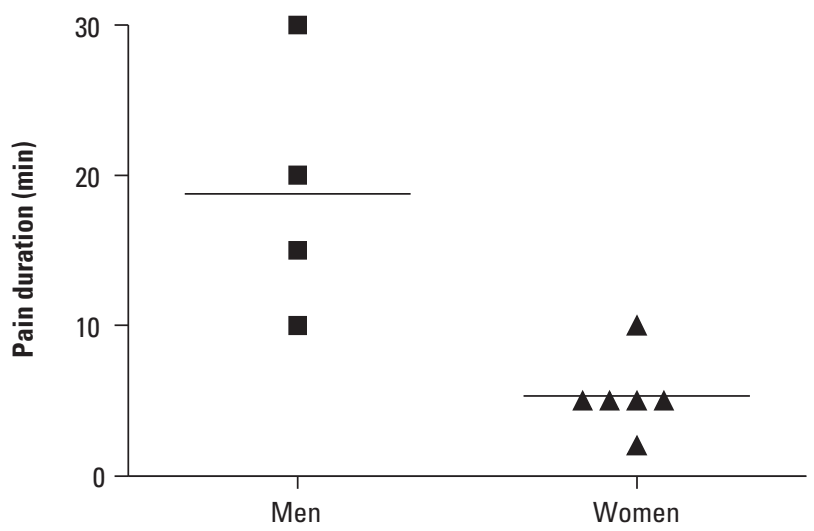

Fig 1. Duration of the Valsalva-related headache.

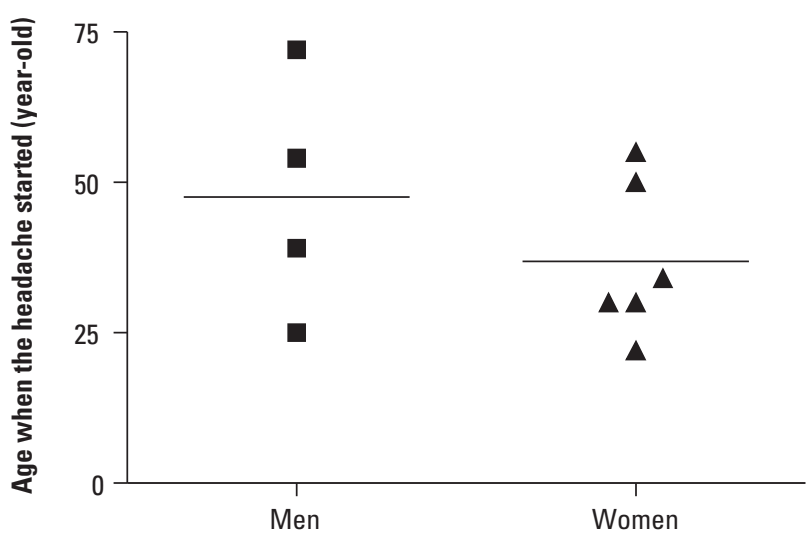

Fig 2. Age at which the headache started. Valsalva-precipitated headaches usually appeared between 22 and 72 years of age in our cases.

(1/10). The patients' mean age at the onset of the Valsalva-related headache was $39.9 \pm 15.7$ years. No differences were observed between men $(47.5 \pm 20.1 \mathrm{y})$ and women (36.8 \pm 12.8 y) ( $\mathrm{p}=0.4762$, Mann-Whitney U test).

The duration of the Valsalva-related headache was $10.7(2-30) \pm 8.7 \mathrm{~min}$. The headaches were of significantly shorter duration in the women compared with the men $(5.3 \pm 2.6 \mathrm{~min}$ versus $18.8 \pm 8.5 \mathrm{~min}, \mathrm{p}=0.0095$ in the Mann-Whitney U test) (Fig 1).

The frequency of headache was relatively high, and all of the patients with Valsalva-related headache suffered from at least one episode per month (Table). The occipital region was involved in eight patients $(80 \%)$ and the frontal region in six patients (60\%).

\section{DISCUSSION}

In the present study, nine out of 19 patients (52.6\%) with CM-1 reported the presence of headaches precipitated by Valsalva maneuvers. Even though CM-1 is considered to be a congenital malformation, the Valsalva-precipitated headaches usually appeared in adults (between
22 and 72 years of age in our cases) (Fig 2). No age difference was noticed between genders, but the duration of the short-lived Valsalva-related headaches was shorter in the women than in the men. This may be explained by at least two factors: anatomical differences and pain threshold.

Headache is a common symptom among patients with $\mathrm{CM}-1^{15}$. Stovner, evaluating 34 patients with CM1 found a high prevalence of headache $(58.8 \%)^{9}$. The pain associated with CM1 seems to be predominantly in the occipital area ${ }^{16}$. Pascual, evaluating 17 patients with headache associated with CM1, encountered pain in the occipital area in all cases ${ }^{12}$.

A study evaluating CSF flow dynamics in patients with CM-1 demonstrated that occipital headache was associated with CSF flow obstruction at the magnum foramen level. These data have importance in surgical indications for CM-1 when headache is the only complaint ${ }^{17}$. In this paper, most of the patients reported occipital pain, in conformity with data in the literature.

In this study, we found six patients that presented headache triggered by coughing, six that presented the precipitating factor of sexual activity and five that had headache triggered by physical effort (generally through lifting some weight). We also identified a patient with headache triggered by sneezing and another by laughing. There is a well-established association between symptomatic cough headache and $\mathrm{CM}-1^{10}$. In a series of 30 cases, all were associated with $\mathrm{CM}-1^{13}$. Although uncommon, effort, laughing and sneezing have also been associated with $\mathrm{CM}-1^{15,18}$.

Headache associated with sexual activity may be a primary entity, but it is generally a manifestation of subarachnoid bleeding $^{19}$. Data correlating CM-1 and sexual activity are very rare in the literature. Farias studied two cases of headache in CM-1 cases that were associated with sexual activity ${ }^{20}$. In this paper, we reported six patients with pain precipitated by sexual activity; four of them with localized pain in the occipital region, thereby increasing the likelihood of an association with CM-1.

The mechanism for headache in CM-1 cases is not well known. It might be associated with a valve-like blockage by $\mathrm{CM}-1$ at the foramen magnum, following Valsalva maneuvers that produced pain due to traction and pressure on sensitive structures ${ }^{15}$. The pathophysiological mechanisms underlying headache attributed to CM-1 seem to be similar among all the cases reported, but the clinical form and various different triggers may cause difficulty in diagnosis.

\section{REFERENCES}

1. Farias da Silva W. Diagnósticos das cefaléias. São Paulo: Lemos 2003;3:35-38.

2. Caetano de Barros M, Azevedo Filho HC, Spinelli C. Disturbances of sexual potency in patients with basilar impression and Arnold-Chiari malformation. J Neurol Neurosurg Psychiatry 1975;38:598-600. 
3. Marin-Padilla M, Marin-Padilla TM. Morphogenesis of experimentally induced Arnold-Chiari malformation. J Neurol Sci 1981;50:29-55.

4. Schijman E. History, anatomic forms, and pathogenesis of Chiari I malformations. Nerv Syst 2004;20:323-328.

5. Ah M. Primary craniovertebral anomalies and the hindbrain herniation syndrome (Chiari 1): data base analyses. Pediatr Neurosurg 1995;23:260-269.

6. Badie BMD, Batzdorf U. Posterior fosse volume and response to suboccipital decompression in patients with Chiari 1 malformation. Neurosurgery 1995; 37:214-218

7. Silva JAG. Malformações occipitocervicais. Recife: Editora Universitária da Universidade Federal de Pernambuco 2003;5:301-304.

8. Pascual J, Oterino A, Berciano J. Headache in type I Chiari malformation. Neurology 1992:42:1519-1521.

9. Stovner LJ. Headache associated with the Chiari type I malformation. Headache 1993;33:175-181

10. Sociedade Brasileira de Cefaléia. Classificação Internacional das Cefaléias. $2^{2}$ edição. São Paulo, 2004.

11. Dones J, De Jesus O, Colen CB, Toledo MM, Delgado M. Clinical outcomes in patients with Chiari I malformation: a review of 27 cases. Surg Neurol 2003;60: 142-147.

12. Pascual J, Iglesias F, Oterino A, Vazquez-Barquero A, Berciano J. Cough, ex- ertional, and sexual headaches: an analysis of 72 benign and symptomatic cases. Neurology 1996:46:1520-1524.

13. Ertsey C, Jelencsik I. Cough headache associated with Chiari type-I malformation: responsiveness to indomethacin. Cephalalgia 2000;20:518-520.

14. Caetano de Barros M, Farias W, Ataíde L, Lins S. Basilar impression and Arnold-Chiari malformation. J Neurol Neurosurg Psychiatry 1968;31:596-605.

15. Morales-Asin F, Mauri JA, Iniguez C, Larrode MP, Mostacero E. Long-term Evolution of a laughing headache associated with Chiari type 1 malformation. Headache 1998;38:552-553.

16. Khurana RK. Headache spectrum in Arnold-Chiari malformation. Headache 1991;31:151-155

17. McGirt MJ, Nimjee SM, Floyd J, Bulsara KR, George TM. Correlation of cerebrospinal fluid flow dynamics and headache in Chiari I malformation. Neurosurgery 2005;56:716-721.

18. Buzzi MG, Formisano R, Colonnese C, Pierelli F. Chiari-associated exertional, cough, and sneeze headache responsive to medical therapy. Headache 2003:43:404-406

19. Kurita H, Segawa H, Ueki K, Kirino T. A sneezer's headache. Neurology 1999;53: 654-655

20. Farias da Silva W, Moreira P. Cefaléia do tipo tensional e outras cefaléias primárias. Rio de Janeiro: Sociedade Brasileira de Cefaléia, 2005. 